\title{
Tapasztalatok egy manualizált csoportos edukációs programmal az osztályos kardiológiai rehabilitációban
}

\author{
TIRINGER ISTVÁN ${ }^{1 *}$ - NAGY ALEXANDRA² - TELEKI SZIDALISZ ${ }^{3}$ - \\ ŽILINSKI NIKOLETT ${ }^{4}$ - SZABADOS ESZTER ${ }^{4}$ \\ ${ }^{1}$ Pécsi Tudományegyetem, Általános Orvostudományi Kar, \\ Magatartástudományi Intézet, Pécs \\ 2 Állami Szívkórház, Balatonfüred \\ ${ }^{3}$ Pécsi Tudományegyetem, Bölcsésztudományi Kar, Pszichológia Intézet, Pécs \\ ${ }^{4}$ Pécsi Tudományegyetem, Klinikai Központ, I. Belgyógyászati Klinika, \\ Kardiológiai Rehabilitációs Tanszék, Pécs
}

(Beérkezett: 2019. június 24.; elfogadva: 2019. december 21.)

\begin{abstract}
Múhelytanulmányunkban egy olyan új szemléletmódot mutatunk be, amelyet az elmúlt években egy kardiológiai rehabilitációs osztályon múködtetett standard, manualizált betegedukációs program használata során sajátítottunk el. Az edukáció új szemléletében a betegek képessé tevése alapozza meg azt, hogy mindennapi életükben meg tudják oldani a betegségükhöz kapcsolódó problémákat. Ennek kiindulópontja, hogy a betegek az igényeiknek megfelelő információkat kapnak betegségükről és kezelésükről. A betegséggel kapcsolatos reális attitúdök és adekvát készségek megtanulása olyan edukációs módszereket igényel, amelyek célja a betegek aktív részvételének ösztönzése, a betegséggel kapcsolatos saját elképzelések és tapasztalatok megosztása és megbeszélése. Az aktív részvétel segíti a betegek felelősségvállalását és a megtanult képességek átültetését a mindennapi életükbe. A tanulmány további részében ismertetjük „A koszorúér-betegség oktatási programjá" -t, amely saját betegedukációs gyakorlatunk alapjául szolgált. A program öt egymásra épülő modulból áll. Kialakítása multidiszciplináris együttmúködés keretében történt, a kockázati tényezők csökkentésével és az életmód-változtatással foglalkozó részei az egészségmagatartás társas-kognitív folyamatmodelljén alapulnak. Saját tapasztalataink szerint a betegedukációs program múködtetését nagymértékben segíti strukturáltsága és részletes kidolgozottsága. Ezek nemcsak fontos feltételei az edukáció minőségének, hanem segítséget adnak az egyes témák megbeszélése során kialakuló csoportdinamikai folyamatok kezeléséhez is. A betegedukációs program standardizált alkalmazása elősegítheti eredményességének és mechanizmusainak empirikus kutatását.
\end{abstract}

Kulcsszavak: betegedukáció, aktív részvétel, képessé tevés, koszorúér-betegség, életmódváltoztatás

\footnotetext{
* Levelező szerző: Dr. Tiringer István, PTE ÁOK Magatartástudományi Intézet, 7624 Pécs, Szigeti út 12. E-mail: istvan.tiringer@aok.pte.hu
} 


\section{Bevezetés}

Tanulmányunkban először azt a szemléletmódot mutatjuk be, amit egy koszorúér-betegek számára kidolgozott manualizált edukációs program múködtetése során sajátítottunk el az elmúlt években. Ezt követően részletesen ismertetjük az általunk használt program manuáljának legfontosabb pontjait, végül kitérünk azokra a saját tapasztalatokra, amelyeket a programmal szereztünk az évek során. Tanulmányunk nem titkolt célja egy későbbi multicentrikus értékelő vizsgálat megalapozása.

Elöljáróban néhány vázlatszerúen felsorakoztatott ténnyel érzékeltetjük napjaink kardiológiai rehabilitációjának kontextusát.

Az iparilag fejlett országokban - Magyarországon is - a szív- és érrendszeri betegségek jelentik a leggyakoribb halálokot. Az elmúlt több mint két évtizedben jelentősen csökkent a szívinfarktus halálozása (Magyarországon 1990-ben 14452-en, míg 2018-ban 5833-an haltak meg akut szívinfarktusban), ugyanakkor egyre többen élnek a koszorúér-betegség következtében kialakuló krónikus szívbetegséggel, s halnak meg végeredményben ennek következtében (KSH, 2019).

Az infarktus bekövetkezte, a katéteres koszorúér-beavatkozás, illetve szívizom-revaszkularizációs mútét után a további lefolyás szempontjából döntő jelentőségú az alapbetegség másodlagos prevenciója ${ }^{1}$, a kockázati tényezők csökkentése vagy megszüntetése. Ez részben a kockázatot hatékonyan csökkentő gyógyszerek adherens szedésével, részben az egészségkárosító életmód megváltoztatásával lehetséges (Niebauer, 2017).

A klinikai vizsgálatok és a mindennapi kezelési tapasztalatok szerint is, a kardiológiai események jelentős érzelmi reakciókat váltanak ki a betegekben, azonban hosszú távon meglepően csekély mértékú életmód-változtatáshoz vezetnek. Az infarktus előtt dohányzó betegek többsége néhány héttel az infarktus után absztinens, többségük azonban egy évvel később már ismét dohányzik (Hajek, Taylor, \& Mills, 2002). A táplálkozási szokások rövid távon szintén jelentős változást mutatnak, idővel azonban a korábbi egészségtelen szokások fokozatosan visszatérhetnek (Leslie, Hankey, Matthews, Currall, \& Lean, 2004). A kardiológiai rehabilitációt követően jelentősen javulhat a fizikai állóképesség, tartós gondozás nélkül azonban ezek az eredmények is bizonytalanok (Bennett, 2017). Egy vizsgálat eredményei szerint az életmód-változtatás csak a betegek egy alcsoportjára

\footnotetext{
1 A klinikai orvostudományokban a szekunder prevenciót abban az értelemben használják, mint ahogy az epidemiológiában és az orvosi szociológiában a tercier prevenciót értjük: a kialakult betegség további progressziójának megakadályozása értelmében. Mivel tanulmányunkkal elsősorban a kardiológiai rehabilitációban dolgozó szakembereket szeretnénk megszólítani, ebben a kontextusban a klinikai medicina terminológiáját használjuk.
} 
jellemző: hat hónappal az akut koronária-szindróma után a terhelhetőség csak azoknál a betegeknél növekedett, akik eleve jelentősebb edzettséggel rendelkeztek, és az alacsonyabb terhelhetőségi szintet mutató betegeknél egyáltalán nem változott. Reménykeltőbb, hogy azoknál a pácienseknél, akik az infarktus előtt viszonylag egészségtelenebbül táplálkoztak, jelentósebb változást tapasztaltak az egészséges étrend irányába, bár ezek a betegek később sem érték el az egészségesen táplálkozók szintjét (Bennett, Gruszczynska, \& Marke, 2016).

Az infarktus utáni 1 éves halálozás Magyarországon 2016-ban 20\% felett volt (STEMI2: 20,4\% ; NSTEMI²: 24,9\%), míg például Svédországban 2014ben 14\%-os gyakorisággal fordult eló (Jánosi, 2017). A rosszabb eredmények mögött számos ok húzódhat meg (Boncz és mtsai, 2019). Ezek között a hosszú távú életmódbeli és szekunder prevenciós gyógyszeres kezelés körüli problémákkal, hiányosságokkal is számolni kell. Az infarktus utáni prognózist befolyásoló tényezők megismerése fontos kutatási feladat, amelynek része az is, hogy a rehabilitációs kezelések és az edukációs programok eredményességével és hatékony mechanizmusaival kapcsolatban megbízható adatokkal kell rendelkeznünk.

Számos klinikai egészségpszichológiai vizsgálat következetes eredménye, hogy a tartós életmód-változtatás esélye jelentősen növekszik, ha a betegek olyan edukációs programban vesznek részt, amely empirikusan alátámasztott elméleteken alapszik (Newman, Steed, \& Mulligan, 2009; Urbán, 2017). Ugyanakkor a kardiológiai betegedukációs programok eredményességét a szíveredetú halálozás csökkentésében egy friss metaelemzés eredményei nem tudták igazolni. Szerzói szerint ennek egyik fontos oka az lehet, hogy a különböző intervenciók eredményei egymással kevéssé összehasonlíthatók, mert egyelőre kevés manualizált és egységesen múködtetett program áll rendelkezésünkre (Anderson és mtsai, 2017).

\subsection{A kardiológiai rehabilitáció célja}

A kardiológiai rehabilitáció célja a kardiovaszkuláris eseményt elszenvedett betegek fizikai, mentális és szociális állapotának javítása, vagyis saját aktív részvételükkel társadalmi pozíciójuk és életvitelük megőrzése, visszanyerése (a WHO (1993) meghatározása, idézi: Veress, Berényi, Szász, \& Sándori, 2010, 617. o.). A rehabilitáció számos olyan elemet tartalmaz, amely a betegek részéről egészségmagatartásuk, illetve életmódbeli szokásaik módosítá-

2 STEMI: az EKG-felvételen az ST-szakasz elevációjával (emelkedésével) járó miokardiális infarktus.

${ }^{3}$ NSTEMI: az EKG-felvételen az ST-szakasz elevációjával nem járó miokardiális infarktus. 
sát igényli. Ebben nyújtanak segítséget a pszichoszociális intervenciók, amelyek felölelik a hangulatzavarok felismerését és kezelését, a stresszcsökkentő módszerek elsajátításának lehetóségét, valamint az életmód-változtatás és a betegségfeldolgozás támogatását (Tiringer, 2017).

\section{A korszerú betegedukáció szemléletmódja}

Egy betegséggel együttélni számos kihívást jelent az érintettek számára. A legtöbb krónikus betegség kialakulása bonyolult, többtényezős folyamat, ugyanakkor ezek a betegségek több életterületre is kihatással vannak.

Krónikus betegségek esetében a kezelés fószereplője hosszú távon maga $a$ páciens, a kezelés az ő mindennapi életében történik. A kihívásokkal történő megküzdéshez a betegeknek megfelelő kompetenciákra van szükségük, amelyekkel kezdetben többnyire még nem rendelkeznek. A megküzdési készségek magukba foglalják a betegséggel kapcsolatos tudást, motivációs és problémamegoldási stratégiákat és konkrét önkezelési készségeket. Azt a folyamatot, amelynek során a beteg abba a helyzetbe kerül, hogy önállóan, felelősséget vállalva meg tudjon küzdeni a betegsége kihívásaival, képessé tevésnek (empowerment ${ }^{4}$-nek) nevezzük (Aujoulat, d'Hoore, \& Deccache, 2007). A képessé tevés alapozza meg, hogy a páciens saját kezébe vegye betegsége menedzselését ${ }^{5}$, ugyanakkor azt is felismerje, mikor van szüksége professzionális segítségre, s hogy a szükségessé váló orvosi döntésekben lehetőleg egyenrangú félként vegyen részt. Krónikus betegségek esetén a képessé tevés módszere a betegedukáció ${ }^{6}$.

Az elmúlt évtizedekben a betegedukáció módszereiben sok újítás történt. Háttérbe szorult a hagyományos frontális oktatás, és meghatározóvá váltak a betegek aktív részvételét ösztönző technikák (Faller, Reusch, \& Meng, 2011). A korszerú edukációs programok a betegek szükségleteiból indulnak ki: problémáik, motivációik és céljaik jelentik a kiindulópontot. Ez a megközelítés elősegíti a páciensek bevonódását, ösztönzi a felelősségvállaló viszonyulásuk kialakulását, és optimális feltételeket teremt a mindennapokba történó átültetéshez.

\footnotetext{
4 Az empowerment fogalom fordítási alternatívája a felhatalmazás, amely jobban kifejezi a felelősség megosztását a pácienssel a kezelés megvalósulásában.

5 Szándékosan használjuk a kezelés/terápia fogalmak helyett a menedzselést ebben a kontextusban. A terápia kialakítása, a beteg gondozása végeredményben az orvos felelössége, de a betegséggel kapcsolatos mindennapi problémák megoldása az edukációban megtanultak alapján a beteg felelőssége. Ez utóbbira használjuk a menedzselés fogalmát.

${ }^{6}$ Célszerú lenne edukáció helyett annak magyar fordítását, az oktatást használni, de azért maradunk az edukáció mellett, mert az egyértelmúbben utal a betegoktatás korszerú felfogására.
} 
Az edukációs programokban a résztvevők aktiválása például az előadásokhoz kapcsolódó csoportos megbeszélés és önálló munka során történik. E módszerek segítik, hogy az elhangzott információk hozzákapcsolódhassanak a résztvevők előzetes tudásához, szubjektív betegségfelfogásához, s hogy az aktivitásukon keresztül jobban rögzüljön a tanulás eredménye. A betegek viszonyulásának változását is csak akkor tudjuk elérni, ha aktiválódnak az adott témával kapcsolatos korábbi elképzelései, érzelmei, motivációi. Az önállóan kialakított, saját véleményekkel szemben kisebb az ellenállás, az ambivalencia, és azok stabilabban rögzülnek, mint a szakemberek által nyújtott kész megoldások (Faller és mtsai, 2017).

\subsection{A professzionális szerep változása}

A betegedukációban a képessé tevés koncepciója és a módszertani újítások a professzionális szerep megváltozásához vezettek. A betegség menedzselésének felelőssége egyértelmúen a páciensé. A szakembernek ${ }^{7}$ el kell ismernie, hogy a főszereplő a páciens. Hogy ez mennyire nehezen vagy könnyen megy neki, azt az alábbi kérdések segítenek megítélni (Anderson \& Funnell, 2004):

- Elvárom-e a betegtól, hogy életmódját az én szakmai véleményem alapján alakítsa?

- Felelősnek érzem-e magam a beteg egészségéért?

- Próbálom-e a beteget meggyőzni arról, hogy kövesse a tanácsaimat?

- Csalódott vagyok-e, ha a páciens nem szívleli meg a javaslataimat?

- Úgy érzem-e, hogy azok a betegek, akik nem együttmúködőek, aláássák a munkámat?

A betegedukációban a szakembernek csupán támogató szerepe van. Segít a betegnek, hogy megszerezze azt a tudást és azokat a képességeket, amelyek szükségesek ahhoz, hogy ki tudja választani a megfelelő kezelési alternatívát. Megkönnyítheti a betegnek, hogy kézbe vegye a betegsége menedzselését azáltal, hogy információt ad, illetve megbeszéli a különböző kezelési módszerek és az életmód-változtatás előnyeit és hátrányait, segít átgondolni a belső és külső akadályokat, amelyek a változtatás ellen hatnak. Végeredményben azonban el kell fogadnia, ha a páciens mégsem azt szeretné, amit ő. Ha a képessé tevésért a felelősség a szakembernél marad, fennáll

\footnotetext{
7 A kardiológiai rehabilitációban: orvosnak, pszichológusnak, gyógytornásznak, dietetikusnak, egészségnevelőnek
} 
annak a veszélye, hogy a beteg függő helyzetbe kerül. A képessé tevésért maga a páciens a felelős: senkit sem lehet az akarata ellenére képessé tenni. A képessé tevés csak az önsegítés támogatása lehet (Faller, 2017). ${ }^{8}$

\subsection{A betegedukációs programok gyakorlati megvalósítása}

A betegedukációs programok a korszerú egészségügyi ellátásban a különböző krónikus betegségek kezelésének standard részévé váltak. Az edukáció minősége csak úgy biztosítható, ha a megvalósítás strukturált formában történik, s az adott program manuálján alapul. A manuálok ismertetik a program elméleti alapjait, a megvalósítás módszereit, pontos lépéseit, és azokat konkrét példákkal illusztrálják. A manuálok egy része a programmal kapcsolatos visszajelzésekre, értékelésre is tartalmaz rövid kérdőíveket (mind a betegek, mind a professzionális oldal részére, adott esetben pedig független, külső értékelők számára is).

A betegedukációs programok nagyon népszerúvé váltak, de kidolgozásuk és megvalósításuk során sokszor tapasztalhatók hiányosságok. A következőkben szeretnénk röviden bemutatni azt a modellt, amelyet Németországban a betegedukáció minőségének ösztönzésére alakítottak ki. Németországban az egészségügyi rehabilitáció finanszírozása a nyugdíjbiztosítás feladata. Érthetó módon, a nyugdíjbiztosítás kifejezetten érdekelt a rehabilitációs kezelések eredményességében, és a tartós munkaképességcsökkenés elkerülésében, illetve enyhítésében. A Német Nyugdíjbiztosítók Szövetsége létrehozott egy betegedukációs centrumot (Zentrum Patientenschulung, http:/ / www.zentrum-patientenschulung.de), amelynek feladata az egészségügyben használt betegedukációs programok optimalizálása.

\footnotetext{
8 Ez a gondolkodásmód látszólag ellentétben áll Miller és Rollnick (1991) motivációs interjús szemléletével, amely szerint az egészségi kockázatot jelentő szokások és addiktív viselkedésformák megváltoztatásában a segító szakember feladatának inherens része a beteg következetes motiválása - ez a szakember felelőssége. Szerintünk azért nincs ellentét a betegedukáció és a motivációs interjú szemlélete között, mert az előbbiben a beteg felelőssége összességében vonatkozik a krónikus betegség menedzselésére. Ezzel kapcsolatban a segító szakember célja a beteg kompetenciaérzésének, felelősségvállalásának erősítése. Ez összhangban áll Rollnick, Miller és Butler (2007) RULE-alapelveivel, amikor azt javasolják, hogy a szakember tartózkodjon (R resist) az utasításoktól, és a páciens képessé tevésére (E - empower) törekedjen. Emellett azonban, a betegség önmenedzselése részeként problémássá váló egészségtelen szokások megváltoztatásában a szakembernek kezdeményező szerepe van és célszerú a beteg változtatással kapcsolatos ellenállását a motivációs interjú szemléletének megfelelóen kezelnie.
} 
A centrum alapvető célja a jelenlegi gyakorlat és az edukáció minőségi standardjai közötti különbség csökkentése. Ennek módja a betegedukációs koncepciók kialakítása, elméletileg megalapozott programok kidolgozása, manualizálása, hatékonyságvizsgálatainak megtervezése és megvalósítása, valamint a programok vezetéséhez szükséges kompetenciák, minőségbiztosítási standardok közvetítése. Jelenleg (2019. június 4-én) a centrum honlapján 159 manualizált betegedukációs program érhető el, amelyeket különböző krónikus betegséggel élők ellátásához, illetve a betegségkockázatot növelő életmódbeli szokások megváltoztatásának támogatásához dolgoztak ki.

\section{Manualizált csoportos betegedukációs program alkalmazása a kardiológiai osztályos rehabilitációban}

Tanulmányunk további részében egy kardiológiai rehabilitációs osztályon 6 év óta múködő edukációs programot mutatunk be, majd beszámolunk saját tapasztalatainkról.

Az osztályon kialakított betegedukációs programban a „Curriculum Koronare Herzkrankheit" (A koszorúér-betegség oktatási programja; Seekatz és mtsai, 2011) elemeit adaptáltuk, amely a fentebb ismertetett német betegedukációs centrum egyik programja. Ezt az empirikusan megalapozott egészségpszichológiai modell alapján múködő programot akut koronáriaeseményen átesett betegek számára dolgozták ki.

A betegedukációs program kiindulópontja egy olyan koszorúér-betegség modell, amely komplex, megalapozott, ugyanakkor jól érthetó, és a befolyásolási lehetőségeket hangsúlyozza. A program abban támogatja a pácienseket, hogy betegségük kezelésével kapcsolatban képessé váljanak tájékozott döntésekre és elkötelezett együttmúködésre. A betegedukáció ösztönzi azon kompetenciák kialakítását, amelyek a szívbetegséget kedvezően befolyásolják, és beilleszthetők a betegek mindennapjaiba.

Ezen átfogó célok megvalósításához:

1. A betegek információkat kapnak szívük múködéséról, koszorúér-betegségük okairól és tüneteiról, valamint a gyakori további következményekről (szívelégtelenség, szívritmuszavarok). A páciensek lehetóséget kapnak személyes kockázati és protektív tényezőik átgondolására, és ösztönzést arra, hogy a célértékek tükrében saját értékeik változását kövessék.

2. A csoportos edukáció során megbeszélésre kerülnek a legfontosabb gyógyszeres és más intervenciós kezelési módszerek, továbbá olyan stratégiák, amelyek hozzájárulnak az adherens gyógyszerszedéshez.

3. A betegek információt kapnak a betegséghez kapcsolódó, a mindennapokat érintó gyakori, tipikus változásokról. Megbeszélésre kerülnek az akut betegségtünetek megfelelő kezelése, az ilyen helyzetekre történő adekvát 
reagálás, másrészt a betegség rövid- és hosszú távú hatása a páciensek múködési szintjére és érzelmi állapotára, valamint a szívbetegségben gyakori pszichés zavarok.

4. A betegek a csoportos megbeszélések során alapvetó életmódbeli javaslatokat kapnak, ezeket összevethetik korábbi ez irányú tapasztalataikkal, ami megalapozza az életmód-változtatási törekvéseiket. A személyes kockázati tényezők átgondolása erősíti a változtatási szándékot, a változtatással kapcsolatos korábbi pozitív tapasztalatoké pedig a személyes hatékonyság elvárását.

5. A motiválás mellett további cél, hogy a betegek a rendszeres testmozgással és az egészséges táplálkozással kapcsolatban olyan kompetenciákat sajátítsanak el, amelyek önállóan kivitelezhetők, és a mindennapokban hosszú távon fenntarthatók.

\section{1. „A koszorúér-betegség oktatási programja” kialakítása}

A program kialakítása során az edukáció tartalmi szempontjait és annak az egyes modulokban történő kapcsolódásait a 2010-ben elérhető kezelési útmutatók és terápiás standardok alapján alakították ki, amelyeket azonban folyamatosan aktualizálni szükséges (pl. Piepoli és mtsai, 2016 alapján). Az edukáció alapprogramjában a szívbetegséggel, annak következményeivel, diagnosztikai és kezelési lehetőségeivel kapcsolatos információk állnak a középpontban. Az információk átadásán túl lényeges szempont a betegséggel történő megküzdés támogatása és a további kezeléssel történő együttmúködésre és a felelősségvállaló attitúdre történő motiválás.

A program öt témára specifikus, egymást kiegészítő, 45-60 perces modulból áll (a modulok áttekintését lásd az 1. táblázatban). A modulok sorrendjét az egymásra épülő tartalmak határozzák meg. Minden modul egy áttekintéssel kezdődik, amely tartalmazza a keretfeltételeket (téma, forma, időtartam), a tanulási célokat, valamint a kivitelezéssel kapcsolatos szempontokat. Ezt követi a tanulási célok megvalósításához adott útmutatás, amely meghatározza a tartalmat, a lefolyást, a didaktikai módszereket, valamint az időkeretet. 
1. táblázat. „A koszorúér-betegség oktatási programja” moduljainak összefoglalása (részletesen azok a modulok [3-5.] szerepelnek, amelyeket a saját gyakorlatunkban rutinszerúen használunk)

1. modul: Az alapok megismerése: a koszorúér-betegség kialakulása, okai, tünetei, kockázati és protektív tényezői.

2. modul: Az orvosi kezelési lehetőségek megismerése: sebészeti eljárások, katéteres beavatkozások, gyógyszerek.

3. modul: A szívbetegség akut tüneteinek adekvát önmenedzselési készségei. Megküzdés a betegségból adódó mindennapi nehézségekkel.

Téma: Megküzdés a szívbetegség mindennapi következményeivel, a korlátozottsággal és az érzelmi megterheléssel.

Tanulási célok:

- A beteg tudja megnevezni, hogy a mindennapi élet mely területein jelentkezhetnek nehézségek, akadályozottság; tudjon megnevezni megfelelő személyes megküzdési stratégiákat.

- A páciens tudja felismerni a koszorúér-betegség következtében kialakuló érzelmi megterhelés tüneteit és a megfelelő támogatási lehetőségeket.

4. modul: A kockázati tényezők és az életmód - krónikus stressz, testmozgás, táplálkozás, dohányzás - megváltoztatása.

Téma: Az egészségmagatartással kapcsolatos javaslatok, az életmód és az életmódváltoztatás átgondolása.

Tanulási célok:

- A beteg tudja megmondani, hogy melyek az életmóddal - a testmozgással, a táplálkozással, dohányzás abbahagyással és a stresszkezeléssel kapcsolatos ajánlások.

- A megismert ajánlások tükrében a páciens gondolja át személyes kockázati tényezőit és az azokkal kapcsolatos szándékait.

5. modul: A kockázatot csökkentő magatartásformák megvalósítása és szokássá válása a mindennapokban.

Téma: Az életmód-változtatás megvalósítása: tervezés, akadályok, a saját viselkedés monitorozása.

Tanulási célok:

- A beteg tudja megnevezni a viselkedés tervezésének lényeges pontjait, túzzön ki konkrét célokat az életmód-változtatással kapcsolatban, egy vagy több területen.

- A beteg azonosítsa a változtatás lehetséges akadályait, dolgozzon ki megfelelő ellenstratégiákat és támogatási lehetóségeket.

- A beteg dolgozzon ki cselekvési és megküzdési tervet az életmód-változtatási célokhoz kapcsolódóan.

- A beteg legyen képes mindennapi életében alkalmazni a viselkedésellenőrzés technikáit.

A manuálban előre megadott példák szerepelnek az egyes modulok központi témájának megfogalmazásához, valamint a konkrét megvalósítás módszereihez. Ezek segítik a pontosabb megvalósítást, de nem szó szerint alkalmazandók. A példák között szerepelnek a megvitatást ösztönző kérdések, valamint a betegeknek szóló instrukciók. 
Kedvező, ha az öt modul a rehabilitáció időszakában egyenletesen oszlik el. A 4. és 5. modul - lehetőség szerint - a rehabilitáció utolsó hetében kerül sorra, mivel ezek a rehabilitáció során szerzett tapasztalatokra épülnek, és az életmód-változtatásnak a rehabilitáció utáni - az otthoni mindennapokban történő - megvalósítására irányulnak.

\subsection{A program elméleti megalapozása: a HAPA-modell}

A betegedukáció során a kockázati tényezőkkel összefüggó életmód-változtatás (testmozgás; táplálkozás; a dohányzás elhagyása; a stressz csökkentése, illetve adekvát kezelése) ösztönzése során elméletileg megalapozott viselkedés-prediktorokra koncentrálunk. A programban az intervenciók elméleti alapja a viselkedésváltoztatás társas-kognitív folyamatmodellje (Health Action Process Approach, HAPA; Schwarzer, 2008). A modell tényezóinek jelentőségét és azok összefüggéseit számos kutatás eredménye megerősítette (Schwarzer \& Luszczynska, 2015). A HAPA-modell szerint az egészségmagatartás - az életmód - megváltoztatása egy önszabályozási folyamat eredménye, amelyben megkülönböztethető egy motivációs és egy akarati (volicionális) szakasz. A motivációs szakasz a szándék megformálásához, az akarati szakasz pedig a tényleges egészségviselkedéshez vezet. A motivációs és az akarati fázist más-más társas-kognitív tényezők jellemzik. A HAPA-modell szerint a kezdeti, motivációs szakaszban a kockázat észlelése, az észlelt kimeneti elvárások és a személyes hatékonyságérzés együttesen befolyásolják a szándék kialakulását. Az akarati szakaszban a személy megpróbálja elérni a kitúzött célját: megtervezi a részleteket, elkezdi a cselekvést, erőfeszítéseket tesz a sikeres megvalósítás érdekében, próbál kitartani; egy kényszerszünet vagy kudarc után újrakezdi célja megvalósítását (Teleki \& Tiringer, 2017).

A kardiológiai rehabilitációban résztvevő betegek esetében a krónikus betegségból, illetve a terápiás megközelítésekből adódóan jelentős hangsúlyt kapnak az akarati szakasz problémái, s az ehhez kapcsolódó intervenciós stratégiák. A metaanalízisek eredményei alapján a változtatás volicionális fázisában viselkedéses technikák - többek között az önmegfigyelés, a célok meghatározása és megtervezése - célravezetőek (Conn, Hafdahl, Brown, \& Brown, 2008; Michie, Abraham, Whittington, McAteer, \& Gupta, 2009).

\footnotetext{
9 Ralf Schwarzer eredeti német elnevezése (sozial-kognitives Prozessmodell des gesundheitlichen Handelns) informatívabb, mint az angol fordítás, mert nemcsak a magatartás megváltoztatásának folyamat jellegét hangsúlyozza, hanem kiemeli a szociális-kognitív tényezők szerepét is.
} 
A HAPA-modell tényezőihez hozzárendelt intervenciós technikákat a program 1., 4., 5. moduljaiba lehet integrálni. Az 1. és 4. modulok a motivációt ösztönző tényezőkkel foglalkoznak (informálás az egészségmagatartással, valamint a kockázati és protektív tényezőkkel kapcsolatban, ezek személyes értékelése, a pro és kontra érvek átgondolása, valamint a konkrét szándékok támogatása). Az intervenciók célja az életmód-változtatás szándékának és konkrét céljainak ösztönzése. Az 5. modul pedig az akarati tényezőkre fókuszál (konkrét célok kitúzése, viselkedés- és megküzdéstervezés, önmegfigyelés), ezzel elősegítve a szándékolt változtatás eredményességét és tartósságát.

\subsection{A programban használt módszerek}

\subsubsection{Előadás}

Az előadás célja a strukturált információátadás, amelynek során a csoportvezető célzottan ösztönzi a kapcsolódó megbeszéléseket. (A megbeszélés általában az előadás során felmerült kérdésekből indul ki, vagy a csoportvezetők az előadás során tapasztalt nem-verbális megnyilvánulásokra reagálnak. Az előadás ilyen módon mindig a megbeszélés keretébe ágyazódik). A párbeszéd kialakulását ösztönzik a csoportvezető által feltett valódi vagy szónoki kérdések. Az előadás során lehetséges PowerPoint diasort alkalmazni, áttekintő ábrákkal és grafikonokkal. Az érthetőség érdekében fontosak a magyarázó hétköznapi példák, a jól követhető szóhasználat, és a szakkifejezések hétköznapi nyelvre történő lefordítása.

\subsubsection{Megbeszélés/megvitatás}

A megbeszélésnek részben a tanulást megalapozó, részben azt ellenőrző funkciója van. A csoportvezetó visszajelzést kap a résztvevők azon ismereteiről és elképzeléseiről, amelyek az egészség- és betegségmagatartás alapjául szolgálnak. A páciensek jellegzetes elképzelései a későbbi csoportmunka során is a megbeszélés fókuszába kerülhetnek.

A csoportvezetók részben egyenrangú partnerek, részben a megvitatás ösztönzói és moderátorai. Fontos, hogy a csoporttagok minél többen és aktívabban vegyenek részt az adott téma megvitatásában. A megbeszélés során - ha szükséges - kiegészítjük, pontosítjuk a betegek tudását, segítjük saját viszonyulásuk átgondolását. A megbeszélésekre általában a résztvevők kifejezett érzelmi bevonódása jellemző. Az eljárás különösen alkalmas olyan tanulási célok esetében, amelyek az attitúdök változását és a problémák megoldását támogatják. 
A csoportvezetők célzott ösztönzéseket alkalmaznak, de visszafogottak a nézőpontok és vélemények értékelésében, ezt átengedik a csoportnak, a zsákutcába vezető elképzeléseket azonban korrigálják. A kérdések segítik a beszélgetés menetének irányítását. Célszerú az egyes témák megvitatását összefoglalással lezárni, vagy a nyitva maradt kérdéseket az előadás további részeibe történő átvezetéshez használni.

\subsection{3. Önálló munka}

Az egyéni munka során a résztvevők a betegségükkel, kezelésükkel összefüggő személyes tényezőket, valamint az életmódjukkal kapcsolatos elképzeléseiket, szándékaikat, terveiket gondolják át a rehabilitáció utáni időszakra, otthoni helyzetükre vonatkozóan. Az önálló munkához kidolgozott munkalapok állnak rendelkezésre. A munka részben „házifeladatok” megoldásával történik.

\subsection{A programmal kapcsolatos empirikus vizsgálat eredményei}

Meng és munkatársai (2014) osztályos rehabilitációs programban résztvevő 434 beteg adatai alapján, egy multicentrikus, kvázi experimentális (de gondosan kontrollált) követéses vizsgálat keretében értékelték a program eredményességét. A vizsgálat elsődleges kimeneteként a betegséggel és a kezeléssel kapcsolatos tudást, a rendszeres testmozgást, az egészséges étrendet és az adherens gyógyszerszedést vizsgálták. A követéses vizsgálat 6 és 12 hónappal az osztályos kezelés lezárását követően történt. Egy évvel az edukációs programban történt részvételt követóen a betegedukációs intervencióban részesüló páciensek betegséggel kapcsolatos tudása szignifikánsan nagyobb volt, több intenzív testmozgást végeztek, viszont táplálkozási szokásaikban és gyógyszeres adherenciájukban nem volt lényegi különbség a szokványos kezelésben részesült betegekhez képest. A részleges eredménytelenség lehetséges okairól a szerzók beható elemzést adnak. A feltételezhető okok közül talán a legfontosabb, hogy a program egyszerre több tényező megváltoztatását ösztönözte - ami általában kevésbé eredményes, mint egyetlen célviselkedés módosítása -, illetve, hogy a tartósabb eredmények érdekében a program lezárását követóen is szükség lehet a tapasztalatok átbeszélésére, és a tanultak felfrissítésére. 


\section{Tapasztalataink "A koszorúér-betegség oktatási programjá"-val}

Az előzőekben bemutatott betegedukációs programot egy belgyógyászati egyetemi klinika keretében múködő önálló kardiológiai rehabilitációs osztályon alkalmaztuk. Az osztály 30 ággyal múködik, a betegek közel fele bypass-mútét vagy akut kardiológiai esemény után - rekonvaleszcens (lábadozó), posztakut fázisban -, fennmaradó része pedig krónikus szívbetegsége miatt programozottan kerül felvételre a háromhetes rehabilitációs kezelésre.

Az általunk kialakított programban a fent bemutatott 5 modul (1. táblázat) közül a 3-5. modulokat - a program „pszichológiai” részeit - tudjuk stabilan múködtetni az osztályon ${ }^{10}$. Ebból a három modulból a háromhetes rehabilitációs kezelés során minden héten egyet-egyet dolgozunk fel. A csoportot pszichiáter-pszichoterapeuta szakorvos és egy képzésben lévő klinikai szakpszichológus vezeti, 6-15 páciens részvételével, 40-50 perces idókeretben.

A betegek az osztályra történő felvételkor írásos tájékoztatást kapnak a múködési keretekről; ezen belül információt a rehabilitációs kezelés részét képező pszichológiai csoportokról: a heti egy-egy alkalommal múködő stresszkezelő csoportról, illetve betegség-feldolgozás/életmód csoportról. Ez utóbbi a betegedukációs csoport.

A páciensek az első edukációs alkalommal tájékoztatást kapnak a csoport jellegéról, az alapvető csoportszabályokról (pl. a titoktartás fontosságáról), és arról, hogy a csoportfoglalkozásokon a koszorúér-betegséghez kötődő pszichológiai természetú problémákról lesz szó, amelyek egy lelkileg egészséges ember számára is nehézséget szoktak okozni. Ezzel a tájékoztatással próbáljuk csökkenteni a stigmatizációtól való félelmüket, ami azért fontos, mert többségük korábban még nem állt kapcsolatban pszichológiai segítővel, és a csoportos pszichológiai munka ismeretlen helyzet a számukra. A bevezetőben azt is hangsúlyozzuk, hogy a csoportban a hozzászólás nem kötelező, de biztatjuk a betegeket, hogy nyugodtan kérdezzenek és mondják el a véleményüket, mert minden megosztott kétely, probléma és megoldás gazdagítja a csoport egészét.

\footnotetext{
10 Az 1. és 2. modul a program orvosi edukációs része, amelyeket tartósan nem tudtunk megvalósítani az osztályon (csak az osztályvezetó orvos dolgozik stabilan az osztályon, a még nem rehabilitációs szakorvos, második orvosok között nagy a fluktuáció). Az osztályon dolgozó orvosok azonban ismerik a kardiológiai alapozó modulokat és azzal összhangban lévő szemléletben végzik rehabilitációs tevékenységüket.
} 


\subsection{A csoporttagok kiválasztása}

A csoporton való részvételi arány magas. Az összeállításnál figyelembe vesszük a páciensek rekonvaleszcens vagy krónikus betegségstádiumát. Visszatérő dilemma, hogy a két csoportot együtt vagy külön kezeljük. Mindkét megoldásnak vannak előnyei és hátrányai. Az osztály viszonylag alacsonyabb beteglétszáma miatt többnyire vegyes csoportokkal dolgozunk. A rekonvaleszcens betegek esetében először a betegség feldolgozása van fókuszban. Esetükben a jövőtől való félelem, a gyengeség és a reménytelenség érzései uralkodnak, s ezt gyakran szorongásos, depressziós tünetek kísérik. A programozott rehabilitáció esetén leginkább a koronáriastátusz megőrzése, a betegség progressziójának megakadályozása, és az életmód-változtatás stabilizálása a cél. Ezen betegek tapasztalatai révén az akut eseményen átesett betegek rálátást nyernek a krónikus betegségszak tapasztalataira, és a megküzdési stratégiák hatékonyságára („Már olyan rég volt a mütétük, s ha most ilyen jól vannak, akkor van remény."). Ugyanakkor a sokszor súlyos szívbetegségben szenvedő krónikus betegek nehézségei érzelmileg megterhelők lehetnek a rekonvaleszcens időszakot megélő betegek számára, s ez növelheti a jövőtől való félelmüket.

A betegek többsége érdeklődő, viszonyulásukra leginkább a kíváncsiság jellemző, valamint a betegségükkel összefüggő információk megszerzésére való igény.

Az edukációs csoportot idős (75 év feletti) rekonvaleszcens betegeknek nem szoktunk javasolni, mivel náluk az életmódbeli kockázati tényezőknek kisebb a jelentősége, a változtatási motivációjuk pedig alacsonyabb.

\subsection{A „pszichológiai” modulok múködésével szerzett tapasztalataink}

A harmadik modul az infarktus, illetve a bypass-mútét utáni állapot érzelmi megterheléseivel foglalkozik. Az ezt a témakört feldolgozó csoportülésen szó van az érzelmi túlterhelődéssel, alkalmazkodási nehézségekkel összefüggő, átmeneti szorongásos és depresszív tünetekről - amelyek az egészséges alkalmazkodás részét képezik -, illetve a viszonylag gyakrabban előforduló szorongásos és depressziós zavarokról.

A rövid bevezető előadást követően az alábbi ösztönzésekkel, illetve kérdésekkel vonjuk be a betegeket a téma közös megbeszélésébe:

- Röviden gondolják át, hogy a szívbetegségükkel kapcsolatban milyen problémákra számítanak majd otthon, a mindennapi életük során!

- Mely területeken számitanak arra, hogy a szívbetegségböl adódóan akadályozottságot élnek meg? 
A lehetséges problémák mellett szó esik az adekvát megküzdési stratégiák jellemzőiről, valamint arról is, hogy az érzelmi problémák rosszabbodása, a spontán javulás elmaradása esetén milyen kezelési lehetőségek érhetók el.

A téma megbeszélését két rövid fiktív eset bemutatásával segítjük. Mindkét példa az infarktus utáni időszak alkalmazkodási problémáit és az eltéró megküzdési módok hatásait érzékelteti.

Általában ez a modul váltja ki a legtöbb érzelmet, leggyakrabban a tehetetlenség érzését. A betegek - elsősorban a fizikai munkát végző férfiak szembesülnek a fizikai erőnlétük csökkenésével, s ezt kontrollvesztésként élik meg. Tudatosul bennük, hogy szociális szerepeik valószínúleg változni fognak, ami felveti az önbecsülés megőrzésének kérdését („Mit gondolnak majd rólam az emberek, amikor látják, hogy a feleségem tolja utánam a bevásárlókocsit?”, „Mit érek még, ha már semmilyen munkát nem tudok ellátni a ház körül?”, "Ki fog alkalmazni egy szívmütött embert?"). A nők esetében kissé más kép rajzolódik ki, a hagyományos női szerepeiknek megfelelően. A nőbetegek jellemzően idősebbek, többségük már nyugdíjas, szemben az aktívan dolgozó férfi társaikkal. Az ő esetükben is lényeges a fizikai erőnlét csökkenése, elsősorban azért, mert vagy megözvegyültek, és egyedül élnek, vagy házastársuk krónikus betegsége miatt szükség van az erőnlétükre (,Ki fogja ellátni a férjemet, amíg én beteg vagyok?”). Általános tapasztalat, hogy a problémák megoldásában a nőbetegek könnyebben és gyakrabban használják társas kapcsolataikat („Majd az unokám elintézi...”).

A csoportvezetők feladata ebben a modulban az érzelmi támogatás mellett az információnyújtás, a betegségreprezentációk felmérése, illetve szükség esetén korrigálása. A betegek hajlamosak csak a veszteségre, állapotuk negatív aspektusaira figyelni („,Semmi nem megy. Nem tudok elsétálni a kapuig. Nem fogok tudni dolgozni a kertben."). Ilyenkor fontos kiemelni, hogy a súlyos korlátozottság többnyire átmeneti, s hogy fizikai teljesítóképességük fokozatosan javulni fog. Javasoljuk, hogy az aktuális terhelhetóségüknek megfelelően legyenek aktívak, s vegyenek részt a körülöttük zajló eseményekben. Ennek az alkalomnak a szlogenje: Az a cél, hogy minél egészségesebben legyünk betegek. A betegség elfogadása, illetve a megmaradt és mozgósítható képességek használata közötti egyensúlyozás attitúdje segít azon betegeknek is, akik a betegséget, a függőséget fenyegetettségként élik meg, s akiknél ez sokszor ösztönös hárításhoz, tagadáshoz vezet.

A csoportban az edukátorok támogató attitúdje mellett a társak támogatása is nagyon fontos lehet. A krónikus szívbetegek pozitív példaként szolgálhatnak arra, hogy a gyógyulásra érdemes lassú folyamatként tekinteni.

Ennél a témánál a csoportban gyakran megjelenik a düh, a csalódottság, az értéktelenség, a jövőtől való félelem és a reménytelenség érzése is. Az érzelmek kifejezése néhány beteget zavaróan érint (elsősorban a férfiakat), 
ezért érdemes megbeszélni, hogy mindenki a saját módján reagál az érzelmi megterhelésekre, s hogy a csoporthelyzetben az érzelmek kifejezése teljesen elfogadható, természetes.

Előfordul, hogy az érzelmi megterhelésekkel kapcsolatos beszélgetés komoly indulatokat vált ki néhány betegból. Sérelmeikról beszélnek, vádaskodnak, áldozatnak érzik magukat. Ezeket a megnyilvánulásokat is elfogadjuk, de nem szoktuk mélyebben explorálni, értelmezni, hanem arra ügyelünk, hogy mindenki szót kaphasson, s hogy senki se sajátítsa ki magának a csoporthelyzetet.

A csoportban időnként destruktívabb viselkedésformák is megjelennek, például az azzal kapcsolatos rivalizálás, hogy ki tud jobban megküzdeni a betegségével. Fontos arra ügyelni, hogy a krónikus betegek „,sztorizgatása”, időnként túláradó önbizalma, pozitív emlékezeti torzításai ne nehezítsék meg a lábadozó, alkalmazkodási nehézségekkel küzdő betegek bevonódását a csoportba. A „nehéz” érzelmeket hárító megnyilvánulásokat tapintatosan, de határozottan azzal szoktuk leállítani, hogy felhívjuk a figyelmet az egyéni, és az aktuális helyzetból adódó természetes különbségekre, s az elfogadás fontosságára.

Időnként olyan szívbetegek is részt vesznek a csoporton, akiknek visszatérő/krónikus szorongásos vagy depressziós - kezelt vagy kezeletlen problémáik vannak, akik a betegszerepüknek sokszor nagy érzelmi hangsúlyt adnak, s a csoporthelyzetet ventillálásra használnák. Ezekben a helyzetekben visszatereljük a beszélgetést a csoport eredeti céljaihoz, s a csoportba nehezen integrálható problémákra egyéni konzultációs lehetőséget ajánlunk.

A negyedik modul az életmód-változtatásra motivál ${ }^{11}$. A csoport bevezetőjében el szoktuk mondani, hogy az életmódbeli szokások megváltoztatása azért nehéz, mert többnyire mélyen gyökerező, évtizedek óta rögzült, szinte automatikusan végzett magatartásformák megváltoztatásáról van szó. Ez sok odafigyelést és kitartást igényel, s a változtatás során természetes, hogy lehetnek visszaesések.

Ez a téma sok betegben búntudatot kelt, ezért a csoportdinamika könynyebb szabályozhatósága érdekében a csoport elején el szoktuk mondani, hogy a csoportban az életmód-változtatással kapcsolatban megbízható információkat adunk, segítjük annak személyes átgondolását, s ezzel az önálló döntést. Hangsúlyozzuk, hogy a kockázati tényezőkről történő beszélgetésnek célja nem a betegséggel kapcsolatos felelősség firtatása, hanem a jövő szempontjából annak végiggondolása, hogyan lehet javítani a betegséggel kapcsolatos esélyeken.

11 A harmadik modul megbeszélése a rehabilitáció első hetében történik, a negyedik modulé a második, az ötödiké pedig a harmadik héten kerül sorra. 
A csoportos munkát egy munkalap kitöltésével kezdjük. Ennek során megkérjük a pácienseket, hogy a felsorolt megváltoztatható kockázati tényezők közül (pl. magas koleszterinszint, magas vérnyomás, magas vércukorszint, kevés testmozgás, egészségtelen táplálkozás, dohányzás stb.) válasszák ki azokat, amelyeknél úgy gondolják, hogy személyesen érintettek (ezzel ösztönözzük reális kockázatészlelésüket):

- Kérjük, hogy jelöljék meg, melyek azok a befolyásolható kockázati tényezők, amelyekről azt gondolják, hogy a saját esetükben jelentöséggel birnak! Hogy érzik, melyeket tudnák ezek közül az életmódjukkal pozitív irányba befolyásolni? Mi lenne hosszú távon a legfontosabb változás az egészségük érdekében?

A személyes kockázati tényezők (kockázati profil) megbeszélését követően részletesen elmondjuk, hogy milyen kedvező testi-lelki hatásai vannak a rendszeres testmozgásnak, az egészséges táplálkozásnak, a dohányzás elhagyásának és a stresszkezelő módszereknek. (Az ezzel kapcsolatos információk a pozitív kimeneti elvárások kialakítását célozzák.) Az életmódbeli témák megbeszélésébe bevonjuk a betegeket, lehetőséget adva arra, hogy beszámoljanak a saját, változtatással kapcsolatos tapasztalataikról. (Ennek kapcsán a személyes hatékonyságérzés növelésének lehetőségeit keressük). Például:

- A rendszeres testmozgás a kezelésük fontos része. Milyen tapasztalatokat szereztek ezzel eddig itt az osztályon? Milyen hatással van Önökre a testmozgás? Hogyan érzik magukat a testmozgást követöen?

- Itt az osztályon hangsúlyozottan ügyelnek a kiegyensúlyozott táplálkozásra. Milyen tapasztalatuk van ezzel? Mennyire könnyen megvalósitható valami hasonló az otthoni, családi étkezési szokásokat figyelembe véve? Mire kell a leginkább ügyelniük, hogy a mindennapokban is egészségesen táplálkozzanak? Milyen lehetőségek adottak a mindennapokban az egészségesebb táplálkozásra? (A cél a táplálkozási szokások tartós megváltozása a kiegyensúlyozott, vegyes táplálkozás irányába, ami hosszú távon sokkal eredményesebb, mint a rövid és radikális diéták.)

A csoportülés kb. utolsó harmadában az életmód-változtatással kapcsolatos szándékok és célok átgondolását ösztönözzük. Általában több tényezőn is érdemes lenne változtatni, célszerú azonban az energiákat egyszerre egy területre koncentrálni, s a célok sorrendjét meghatározni. Például:

- Ha a saját kockázati tényezőikre gondolnak, mely szokások megváltoztatása túnik személyesen a legfontosabbnak? Milyen változásokra van leginkább esély a rehabilitációt követó időszakban? Mi az elsődleges céljuk ezzel kapcsolatban?

- Az előbbiekben több változtatási lehetöség is szóba került. Gondolják át a következő hétig, hogy mely területeken szeretnének leginkább változtatni, és mely változtatás egyeztethetó leginkább össze a személyes céljaikkal!

Fontos, hogy a csoportvezetők nem minden áron meggyőzni akarják a betegeket, hanem tájékoztatnak a kockázatokkal és a változtatással kapcso- 
latos tényekról. Cél a kockázatokkal kapcsolatos kompetenciák támogatása, ezen túlmenően azonban mindenki maga dönti el, hogy mennyi kockázatot vállal.

Bár a modul koncepciója a betegek irányában konstruktív és érzelmileg támogató, ennek ellenére nem ritkán tapasztalunk destruktív csoportdinamikai folyamatokat, időnként (általánosságban) az orvosokkal, illetve az aktuális csoportvezetókkel szembeni burkolt vagy nyílt indulatokat is.

A krónikus betegek egy része hajlamos az életmód-változtatással, például a dohányzás abbahagyásával kapcsolatban könnyú sikerekról beszámolni. Ezekben a helyzetekben el szoktuk mondani, hogy a szokások erősségében, a változtatás külső támogatásában nagy egyéni különbségek vannak, ezért természetes, hogy sok esetben jóval több nehézséget kell legyőzni a változás eléréséhez.

Jellemző, hogy a koszorúér-betegek többsége a stresszt és a túl sok munkát teszi felelőssé a betegsége kialakulásáért. A stressz laikus koncepciója a stresszt az élet tehetetlenül, sorsszerúen megélt aspektusaival azonosítja, ami a passzív áldozatszerepet erősíti. Ez a betegségattribúció gyengíti az életmód-változtatás motivációját, ezért erre reagálva el szoktuk ismételni, hogy a koszorúér-betegségnek sok kockázati tényezője van, és bár nehezebb, de a kimenetel szempontjából mégis eredményesebb, ha minden - a célértéktól eltéró - tényezőre odafigyelnek, s igyekeznek azon változtatni.

A motiváció növelésében fontos, hogy az életmódváltoztatás kapcsán ne egyoldalúan a lemondások, illetve a nehézségek hangsúlyozódjanak. Ezért gyakran elmondjuk - s ezt a csoporton résztvevő krónikus betegek is meg szokták erósíteni -, hogy a változtatásnak már rövid távon is lehetnek pozitív következményei. Például a testmozgás jó közérzetet, jó hangulatot eredményez, és az egészséges ételeket is lehet ízletesen elkészíteni.

Az életmód-változtatásra motiválás modul olykor nehezebb csoporthelyzeteket is eredményez. Például időnként megfogalmazódnak az életmódváltoztatást és egyes gyógyszerek szedésének jelentőségét megkérdőjelező vagy leértékelő vélemények. Erre reagálva elfogadjuk a nyílt kommunikációt, a kritikus véleményeket, de röviden el szoktuk mondani, hogy az általunk nyújtott információk összhangban vannak a kardiológiai ajánlásokkal, amelyek megbízható kutatásokon alapulnak. Azt is el szoktuk ismerni, hogy az internet világában sokszor nem könnyú tájékozódni, s eldönteni, hogy kinek higgyünk, de az orvosi információk pont ezért jelentenek fontos tájékozódási pontokat.

A személyes kockázati profil átgondolása és egy konkrét életmód-változtatási szándék kialakítása után az ötödik modulban a konkrétabb tervek kialakításával foglalkozunk. Ez a modul a program leggyakorlatiasabb része, a HAPA-modell volicionális (akarati) fázisához kötődik, és a cselekvéstervezést, illetve a megküzdéstervezést segítő intervenciókat tartalmaz. 
A bevezetőben elmondjuk, hogy a konkrét, részletesen kidolgozott terv - annak átgondolása és rögzítése, hogy mit, mikor, hogyan fogunk tenni a változtatás eredményességének legfontosabb tényezője. A téma átgondolását a rendszeres testmozgás és az egészséges étrend megtervezését segító munkalappal folytatjuk. Ennek instrukciója így hangzik:

- A konkrét tervek fontos lépést jelentenek afelé, hogy a szándékokat az életmódváltoztatással kapcsolatban a mindennapokban is keresztül tudják vinni. Csak az képes erre, akinek konkrét tervei vannak arra, hogy a szándékait hogyan valósitja meg. Fontos, hogy ne csak tervet készítsenek, hanem készüljenek fel a várható akadályokra, amelyek meghiúsíthatják a tényleges változtatást.

A tervek csoportos megbeszélését követően a vezetők röviden összefoglalnak néhány bevált stratégiát, amelyek segítik az akadályokkal történő megküzdést. Például:

- kerülni azokat az információkat, amelyek elterelik a figyelmet;

- a tervezésben figyelembe venni a hangulat, a fáradtság természetes napszaki változását;

- kezdést segítő stratégiákat használni (pl. az egészséges ételek listáját bevásárlás során), társas támogatást igénybe venni;

- a tervezett idópontokat a naptárba rögzíteni, ezzel mintegy „bebiztosítva" azokat más vonzó programokkal szemben.

Az ötödik modul hangulata többnyire jóval nyugodtabb, és rendszerint kevesebb ellenállást tapasztalunk, mint a motiválásra törekvő megelóző alkalommal. Ez valószínúleg a konkrét feladatoknak és a problémamegoldó attitúdnek köszönhetó, valamint annak az edukációnak és csoportdinamikai munkának, amit az előző alkalommal végeztünk.

\section{5. Összegzés}

A tanulmányunkban bemutatott betegedukációs csoportot egy olyan kardiológiai rehabilitációs osztályon kezdtük el múködtetni 6 évvel ezelőtt, amely akkoriban szerveződött újra egyetemi klinikai keretek között. Az osztály új múködési rendjének kialakítása során a pszichológiai-pszichoszomatikus ellátás kezdettől fogva a rehabilitációs program integráns részét képezte. Az egyik szerző (T. I.) több mint 2 évtizedes tapasztalattal rendelkezik a kardiológiai konzultációs pszichiátriai ellátásban. A klinikai egészségpszichológia fejlődése az elmúlt évtizedekben azonban egyértelmúvé tette, hogy a kardiológiai rehabilitáció korszerú multidiszciplináris megközelítésében egy betegedukációs csoportnak kell a pszichológiai program központi részét képeznie. Az ellátás során emellett továbbra is fontos szerepe van a hagyományos pszichoszomatikus megközelítésnek, elsősorban a depressziós és szorongásos zavarok szúrésének és kezelésének. 
Az elmúlt évek tapasztalatai a kardiológiai rehabilitációs osztályon igazolták a fenti elképzelés helyességét. A betegedukációs program stabil részévé vált a rekonvaleszcens fázisban lévő betegek rehabilitációjának. A koszorúér-betegek nagy többsége részt vesz a csoportjainkon, annak ellenére, hogy a részvétel nem kötelező, csak ajánlott.

A csoportokon azt tapasztaltuk, hogy az edukációs program strukturáltsága nagyon hasznos, mert a pszichológiai csoportmunkára nem szocializált kardiológiai betegeknek nem elég néhány alkalom arra, hogy ráhangolódjanak a szabad interakciós munkamódra. Annak ellenére, hogy a csoportok az elejétől a végéig transzparens témák mentén, előre megadott módszerek segítségével múködnek, az egyes témák által mozgósított csoportdinamika időnként elsodorná a csoportot, ha nem lenne a program struktúrája, amihez mindig vissza lehet térni. Ez azonban a csoportvezetők számára folyamatos feladatot jelent, mert a csoportdinamikai sodrás - pl. a 4., életmód-változtatásra motiváló, a bưntudat témát felkavaró modul esetében - a csoport aktuális összetételétól függően erős tud lenni. Az ilyen csoporthelyzetek kezelésében segít, ha mindjárt a csoport elején expliciten megfogalmazzuk ezeket a jellegzetes problémákat - pl. hogy az életmódváltoztatás témája óhatatlanul búntudatot kelthet, de a csoportfoglalkozásnak nem ez a szándéka, továbbá időperspektívája nem a múlt, hanem a jelen és a jövő. Ha például a csoportban elindul a búnbakképzés, akkor ezt hamar megszakítjuk, visszautalunk a csoport elején elmondottakra, s viszszatereljük a megbeszélést az eredeti témára. Így az is elkerülhetővé válik, hogy a csoport tagjai és a csoportvezetók között hatalmi harc alakuljon ki.

A betegedukációs program alkalmazása során azt is megtapasztaltuk, hogy ha pontosan tartjuk magunkat az adott modul manuálban rögzített struktúrájához, akkor kisebb tere van a téma csoportdinamikai sodrásának. Ez a probléma azonban teljesen nem küszöbölhetó ki, mert a csoporton történő részvételt nem előzi meg pszichológiai szúrés. Ezzel kapcsolatos szempontokat egyébként az adaptált program manuálja sem tartalmaz. Szúrési lehetőséget mindössze az osztályon tapasztalt nyilvánvaló pszichés dekompenzáció jelei adnak.

Összességében azonban a csoportüléseken konstruktív légkört tapasztalunk, a résztvevő betegek többsége megérti az edukáció céljait és azzal azonosulni tud. A visszatéró betegek esetében - akik programozott rehabilitációban vesznek részt - azt érzékeltük, hogy megtanulták már a betegedukációs csoport kultúráját, s ez modellként szolgált az intervencióban először részt vevő új betegek számára.

Annak ellenére, hogy évek óta egy strukturált programmal dolgozunk, nagyjából háromhetes ciklusokban, a csoportvezetők érdekes tapasztalata, hogy a csoportok témái mégsem válnak unalmassá: nincs két egyforma csoport, s mindegyik alkalom tartogat új kihívásokat a számunkra. 


\section{Kitekintés}

A betegedukációs programmal szerzett jó tapasztalataink természetesen nem helyettesíthetik a hatások empirikus vizsgálatát. Ennek feltételei azonban a tanulmányunkban bemutatott kardiológiai rehabilitációs részlegen kevéssé adottak ${ }^{12}$.

A program hatékonyságvizsgálatának feltételei alapvetóen megteremthetők. A manuál fordítását és publikálását követően csoportvezetők képzésével kialakítható egy olyan szakmai csapat, amely megvalósíthatja "A koszorúér-betegség oktatási programjának" multicentrikus vizsgálatát. Ennek elengedhetetlen feltétele lenne, hogy az edukációs program teljes manualizált formáját minden centrumban multidiszciplináris teamek (orvosok részvételével is) múködtessék. Reményeink szerint a tanulmányunkban öszszefoglalt tapasztalatok is segíthetik a tervezett vizsgálatban az edukációs program minél magasabb szintú és egységesebb megvalósítását.

A klinikai egészségpszichológiai szakma egészét érintő problémaként vetjük fel, hogy az egészségügyben strukturált csoportokkal dolgozó pszichológusok számára fontos lenne egy olyan csoportképzés, amely ezen speciális terület igényeinek felel meg. Az általunk ismert csoportképzési programok döntóen a hagyományos csoportterápiás helyzetekre készítenek fel, amelynek fókusza a különböző pszichés zavarok kezelése. Tapasztalatunk szerint annak ellenére, hogy a krónikus testi betegségben szenvedők többsége klinikai értelemben lelkileg egészségesnek tekinthető, bizonyos edukációs témáknál hasonló csoportdinamikai folyamatok múködhetnek, mint egy hagyományos csoportterápiás keretben. Ezeknek a csoportfolyamatoknak a kezelése azonban más készségeket és technikai megoldásokat is megkíván, mint amelyek a hagyományos csoportterápiás képzések keretében sajátíthatók el.

Végül, de nem utolsó sorban szeretnénk egy fontos gyakorlati szempontra is kitérni. Említettük, hogy a pszichológiai-pszichoszomatikus ellátás a kardiológiai rehabilitációs osztály múködésének stabil részévé vált. Emellett azonban úgy gondoljuk, hogy a betegedukációs program koncepciójában az a tágabb lehetôség rejlik, hogy az osztályon folyó multidiszciplináris rehabilitációs tevékenység közös szemléleti keretévé váljon. Az elmúlt évek során a saját egészségpszichológiai megközelítésünket több szakmai fóru-

12 Az osztály kis ágylétszámú, a stáb múködése csak részben stabil. Például a program múködésének 6 éve alatt csak 3+1 évig volt az osztálynak egy-egy fóállású pszichológusa, és a program koedukátorai gyakran az osztályon féléves forgásban dolgozó klinikai szakpszichológus rezidensek voltak. 
mon részletesen kifejtettük ${ }^{13}$ - s ezzel kapcsolatban sok megerősítő, pozitív visszajelzést kaptunk -, de azt a mindennapi rehabilitációs csapatmunkában talán mégsem képviseltük kellő hatékonysággal. Reményeink szerint, saját tapasztalataink átgondolása és jelen tanulmányban történő publikálása segíti és eredményesebbé teszi majd a társszakmákkal történő kommunikációnkat.

\section{Irodalom}

Anderson, L., Brown, J.P.R., Clark, A.M., Dalal, H., Rossau, H.K.K., Bridges, C., et al. (2017). Patient education in the management of coronary heart disease. Cochrane Database of Systematic Reviews, (6).

Anderson, R.M., \& Funnell, M.M. (2005). Patient empowerment: reflections on the challenge of fostering the adoption of a new paradigm. Patient Education and Counseling, 57(2), 153-157.

Aujoulat, I., d'Hoore, W., \& Deccache, A. (2007). Patient empowerment in theory and practice: polysemy or cacophony? Patient Education and Counseling, 66(1), 13-20.

Bennett, P. (2017). Psychological care of cardiac patients. In J. Niebauer (Ed.), Cardiac rehabilitation manual (73-88). Cham: Springer

Bennett, P., Gruszczynska, E., \& Marke, V. (2016). Dietary and exercise change following acute cardiac syndrome onset: A latent class growth modelling analysis. Journal of Health Psychology, 21(10), 2347-2356.

Boncz, I., Sebestyén, A., Csákvári, T., Ágoston, I., Szabados, E., \& Endrei, D. (2019). A kardiológiai rehabilitáció teljesítménymutatói Magyarországon. Orvosi Hetilap, 160(S1), 6-12.

Conn, V.S., Hafdahl, A.R., Brown, S.A., \& Brown, L.M. (2008). Meta-analysis of patient education interventions to increase physical activity among chronically ill adults. Patient Education and Counseling, 70(2), 157-172.

Faller, H., Reusch, A., \& Meng, K. (2011). Innovative Schulungskonzepte in der medizinischen Rehabilitation. Bundesgesundheitsblatt-Gesundheitsforschung-Gesundheitsschutz, 54(4), 444-450.

Faller, H., Reusch, A., \& Meng, K. (2017). Patientenschulung und Psychoedukation. In U. Koch, \& J. Bengel. Anwendungen der Medizinischen Psychologie. Enzyklopädie der Psychologie (163-182). Göttingen: Hogrefe

Hajek, P., Taylor, T.Z., \& Mills, P. (2002). Brief intervention during hospital admission to help patients to give up smoking after myocardial infarction and bypass surgery: randomised controlled trial. BMJ, 324(7329), 87-89.

Jánosi, A. (2017). Szívinfarktus 2016: gyakoriság, ellátás, prognózis. Cardiologia Hungarica, $47(5), 336-340$.

13 Az öt éve minden szeptemberben megrendezésre kerüló Pécsi Kardiológiai Napok programjában kezdettől fogva szerepel egy pszichoszociális szekció, amelynek keretében különböző kardiológiai pszichológiai-szociológiai témákról, és azok gyakorlati aspektusairól tartottunk előadásokat. Ezek egy része írásban is megjelent (Nagy, Tiringer, \& Szabados, 2016). 
Központi Statisztikai Hivatal: 1.5. Halálozások a gyakoribb halálokok szerint (1990-). Letöltve: 2019. 12. 13-án: https://www.ksh.hu/docs/hun/xstadat/xstadat_eves/i_ wnh001.html

Leslie, W.S., Hankey, C.R., Matthews, D., Currall, J.E.P., \& Lean, M.E.J. (2004). A transferable programme of nutritional counselling for rehabilitation following myocardial infarction: a randomised controlled study. European Journal of Clinical Nutrition, 58(5), 778-786.

Meng, K., Seekatz, B., Haug, G., Mosler, G., Schwaab, B., Worringen, U., et al. (2014). Evaluation of a standardized patient education program for inpatient cardiac rehabilitation: impact on illness knowledge and self-management behaviors up to 1 year. Health Education Research, 29(2), 235-246.

Michie, S., Abraham, C., Whittington, C., McAteer, J., \& Gupta, S. (2009). Effective techniques in healthy eating and physical activity interventions: A meta-regression. Health Psychology, 28(6), 690-701.

Miller, W.R., \& Rollnick, S. (1991). Motivational interviewing: Preparing people to change addictive behavior, New York: The Guilford Press

Rollnick, S., Miller, W.R., \& Butler C.C. (2007). Motivational interviewing in health care: helping patients change behavior. New York: The Guilford Press

Nagy, A., Tiringer, I., \& Szabados, E. (2016). Integrált egészségpszichológiai edukációs program alkalmazása koszorúérbetegek rehabilitációjában. Kardiovaszkuláris Prevenció és Rehabilitáció 6(2), 20-22.

Newman, S., Steed, E., \& Mulligan, K. (2009). Chronic physical illness: self-management and behavioural interventions. Maidenhead: Open University Press/McGraw Hill

Niebauer, J. (2017). Secondary prevention: A second chance to make inevitable lifestyle changes. In J. Niebauer (Ed.), Cardiac rehabilitation manual (V-VIII.). Cham: Springer

Piepoli, M.F., Hoes, A.W., Agewall, S., Albus, C., Brotons, C., Catapano, A.L., et al. (2016). 2016 European Guidelines on cardiovascular disease prevention in clinical practice. European Heart Journal, 37(29), 2315-2381.

Schwarzer, R. (2008). Modeling health behavior change. How to predict and modify the adoption and maintenance of health behaviors. Applied Psychology, 57(1), 1-29.

Schwarzer, R., \& Luszczynska, A. (2015). Health action process approach. In M. Conner \& P. Norman (Eds.), Predicting and changing health behaviour: Research and practice with social cognition models (252-278). London: Open University Press

Seekatz, B., Meng, K., Altstidl, R., Haug, G, Mosler, G., \& Schwaab, B. (2011). Curriculum Koronare Herzkrankheit. Berlin, Deutsche Rentenversicherung Bund. Letöltve: 2019. 05. 18-án: http:/ / www.psychotherapie.uni-wuerzburg.de/forschung/herzkrankheit/ Curriculum_Herzkrankheit_Manual_KHK.pdf

Szőnyi, G. (2019). Csoportok és csoportozók. Budapest: Medicina

Teleki, S., \& Tiringer, I. (2017). Az egészségmagatartás változásának szociális-kognitív folyamatmodellje (HAPA-modell). Mentálhigiéné és Pszichoszomatika, 18(1), 1-29.

Tiringer, I. (2017). Pszichoszociális faktorok felismerése és kezelése a kardiovaszkuláris prevencióban. In E. Szabados, M. Tonelli, K. Tóth, P. Vályi, \& A. Vértes (Szerk.), Kardiovaszkuláris prevenció a klinikai gyakorlatban: Útmutató háziorvosoknak, kardiológusoknak (214-228). Budapest: Viviankom-2002 Kft.

Urbán, R. (2017). Az egészségpszichológia alapjai. Budapest: ELTE Eötvös Kiadó

Veress, G., Berényi, I., Szász, K., \& Sándori, K. (2010). Cardiovascularis betegségek utáni rehabilitáció. In Zs. Vekerdy-Nagy (Szerk.), Rehabilitációs orvoslás (617-628). Budapest: Medicina Könyvkiadó Zrt.

WHO (1993). Needs and action priorities in cardiac rehabilitation and secondary prevention in patients with $\mathrm{CHD}$. Copenhagen: WHO, Regional Office for Europe 


\section{Köszönetnyilvánítás}

Köszönettel tartozunk a Julius-Maximilians-Universität Würzburg, Arbeitsbereich Medizinische Psychologie két munkatársának, Prof. Dr. Hermann Fallernak és Dr. Karin Mengnek, hogy lehetővé tették számunkra a "Curriculum Koronare Herzkrankheit" betegedukációs program használatát.

Köszönetet mondunk Dr. Simon Attilának, a Balatonfüredi Állami Szívkórház orvosigazgatójának, hogy kéziratunkat átnézte és értékes javaslatokkal gazdagította.

\section{Szerzói munkamegosztás}

A tanulmány koncepciójának, szerkezetének kialakítása és megszövegezése nagyrészt Tiringer István munkája. Nagy Alexandra, Žilinski Nikolett a tanulmány saját gyakorlatunkat bemutató, 4. részének (Tapasztalatok) megírásában vett részt. Teleki Szidalisz munkája a HAPA-modellt bemutató (3.2.) rész. Teleki Szidalisz és Szabados Eszter a tanulmány megírásának egésze alatt jelentős kiegészítéseket és értékes kritikai megjegyzéseket tett, valamint elkészülte után ellenőrizte azt.

\section{Nyilatkozat érdekütközésról}

A szerzők ezúton kijelentik, hogy esetükben nem állnak fenn érdekütközések.

\section{Experiences with a manualized group patient education program in residential cardiac rehabilitation}

\section{TIRINGER, ISTVÁN - NAGY, ALEXANDRA - TELEKI, SZIDALISZ - ŽILINSKI, NIKOLETT - SZABADOS, ESZTER}

Our publication presents such a new approach to patient education, which we have learned over the past few years by using a standardized, manualized patient education program in residential cardiac rehabilitation. According to this new approach, the empowerment of patients establishes that they can cope with the illness-related problems in their everyday life. The starting point in this process is that patients receive information about their illness and their treatment according to their needs. Learning realistic attitudes and adequate skills requires education methods the aim of which is to promote active participation and to communicate and discuss one's illness-related ideas and experiences. Active participation of patients' supports the development of responsibility and the implementation of the skills learned in the daily life of patients'. In other parts of the publication the program "Curriculum coronary heart disease" is presented, which served as the basis of our patient education practice. This program consists of five consecutive modules, which was developed in a multidisciplinary collaboration. The parts of the program that deal with 
reducing risk factors and changing health behaviour were derived from the established Health Action Process Approach model. In our own experience, the use of this standardized, manualized patient education program is made easy by its structure and extensive elaboration. These characteristics are not only prerequisites for the quality of the application but are also very helpful in regulating the group dynamic processes that can develop when discussing lifestyle change issues. The standardized application of the patient education program can be the basis of its later evaluation and the research of its mechanisms.

Keywords: patient education, active participation, empowerment, coronary heart disease, lifestyle change

A cikk a Creative Commons Attribution 4.0 International License (https:/ / creativecommons.org/ licenses/by/4.0/) feltételei szerint publikált Open Access közlemény, melynek szellemében a cikk bármilyen médiumban szabadon felhasználható, megosztható és újraközölhető, feltéve, hogy az eredeti szerző és a közlés helye, illetve a CC License linkje és az esetlegesen végrehajtott módosítások feltüntetésre kerülnek. (SID_1) 